rami widnieje w kopule napis: ,Tu es Petrus“, a dalej, naokoło nawy, czytamy rozmowe Piotra $z$ Chrystusem nad jeziorem Tyberiadzkim, zakkończoną słowami Boskiego Mistrza: „Pasce oves meas“.

W Offertorium odzywa się głos tychże baranków, podnoszacych ufnie oczy i ręce do Dobrego Pasterza: „Boże, Boże mój, o świcie szukam ja Cieblie, i w Imię Twoje będę podnosić rẹce moje, Alleluja“" (Ps. 62).

W antyfonie, towarzyszącej Komunii, słyszymy raz jeszcze te drogie słowa: ,Jam jest Pasterz dobry, Alleluja, i znam owce moje i znają mnie moje, Alleluja, Alleluja“.

„O święta bazyliko watykańska“ - woła kardynał Schuster w swym „Liber Sacramentorum" - rozprzestrzeń twe obszerne nawy, gdyż nadzieje twoje (uniwersalnego Kościoła), oparte na oblietnicy Jezusowej, nie mogą być zawiedzione“. Dobry Pasterz doprowadzi do swej owczarni nawet owieczki zbłąkane, i ,stanie się jedna owczarnia i' jeden pasterz".

S. Maria Renata, Niep.

\title{
NIEWYCZERPANE BOGACTWA CHRYSTUSOWE
}

(Lekcja we Mszy św. o Najśw. Sercu Pana Jezusa)

Celem uroczystości Najśw. Serca Jezusowego jest wynagrodzenie Boskiemu Sercu za jego bezgraniczną miłość, zapoznaną przez ludzi. Już we wstẹpie Mszy św. wprowadza nas Kościół w wewnętrzny świat Zbawiciela i wyjawia nam jego myśli, zmierzające do odkupienia i zbawienia ludzkości. Na czytanie zaś podaje nam wyjątek z listu do Efezjan (3, 8-19), w którym św. Paweł opisuje owoce odkupienia i wskazuje sposób przyswojenia ich ludziom. Są to niezgłębione bogactwa prawdy i łaski, a otrzymujemy je przez przepowiadanie apostolskie i przez modlitwę.

Przytaczam wyjątek $\mathrm{z}^{-}$listu Apostoła w przekładzie z greckiego, a stẹpnie daje krótki jego rozbiór.

„Mnie najlichszemu ze wszystkich świẹtych została dana ta łaska, zebym głosit poganom niezgłẹbione bogactwo Chrystusa $i$ ośviecat wszystkich, czym jest porzadek tajemnicy, zakrytej od wieków w Bogu, Stwórcy uszystkiego. Ale teraz przez Kościót ma się okazać zwierzchnościom $i$ władzom na niebiosach wieloraka madrość Boga, zgodnie 
z odviecznym postanowieniem, które uczynil w Chrystusie Jezusie, Panu naszym. W nim mamy ufność $i$ śmialy przystẹp, przez wiare $w$ niego. Dlatego proszę, nie upadajcié na duchu z powodu uciskótw mych za was, gdyz to jest chwała wasza.

Dla tej przyczyny zinam kolana przed Ojcem (Pana naszego, Jezusa Chrystusa), od którego bierze swe imiẹ wszystko, co nazywa siẹ ojcostwem $w$ niebie i na ziemi: On niech wam użyczy wedlug bogactwa swej chwały, abyście za sprawa Ducha $S w$. wzmocnili się potęznie w wewnętrznego czlowieka; zeby Chrystus zamieszkat przez wiare w sercach waszych; żebyście, whorzenieni i utwierdzeni w miłości, mogli pojać wraz ze wszystkimi świetymi, jaka jest rozleglość i dalekość, uzniosłość i głẹbia, poznać również mitość Chrystusa, która przewyższa poznanie; abyście zostali napełnieni wszystka pełnościa Bożą“.

W pierwszej części listu św. Paweł przedstawił swym czytelnikom, nawróconym z pogan, jak wielkie i wspaniałe dobrodziejstwa otrzymali od Boga. Wybrani odwiecznie i przeznaczeni do świętości, zostali w czasie odkupieni krwią Syna Bożego. Powołani następnie do wiary i wszczepieni w Chrystusa przez chrzest, stali się uczestnikami wszystkich dóbr mesjańskich, przyobiecanych niegdyś Izraelowi. W ten sposób zrównani zostali we wszystkim $\mathrm{z}$ wiernymi, nawróconymi z żydów. Jedni i drudzy stanowią dziś zgodną rodzinę dzieci Bożych, owszem członkami sa jednego i tego samego mistycznego Ciała Chrystusa, Kościoła. Rozważanie to pragnie Apostoł zakończyć modlitwa o utwierdzenie czytelników w wierze i pogłẹbienie nadprzyrodzonego ich życia. ,Dla tej przyczyny, pisze $(3,1)$, ja Pawet, więzień Jezusa, za vas pogan..." Przy tych słowach stanęło mu żywo w pamięci zadanie, jakie właśnie jemu wyznaczył Bóg do spełnienia w przeogromnym dziele nawrócenia pogan i zjednoczenia wszystkich w Chrystusie. Przerywa wiẹc rozpoczęty tok myśli i jakby w nawiasie opisuje łaskę, którą on, Paweł, otrzymał odnośnie do pogan. W liczbie świętych, apostołów i proroków Nowego Przymierza, jemu również objawił Bóg to, co przez wieki było ścisłą tajemnicą dla wszystkich: że poganie na równi z $\dot{z} y$ dami powołani są do wiary i zbawienia mesjańskiego. Lecz łaską, która wyróżnia Pawła wśród innych apostołów, było przeznaczenie go do głoszenia tej tajemnicy w świecie pogańskim i do wprowadzania pogan do Kościoła. Jego zamianował Chrystus Pan swym posłem do pogan i uczynił go wybranym narzędziem do ich nawrócenia (Dz. 9, 15).

Właśnie ,jemu, najlichszemu ze wszystkich świẹtych, zostało dana ta Kaska". W 1 Kor. 15, 9 nazywa się Paweł najmniejszym z apo- 
stołów, niegodnym nosić tej nazwy dlatego, że ,prześladoual Kościót Boży". Z nienawiścią odnosił się do Jezusa, zwalczał Jego naukę i za wszelką cenę starał się wyrwać $z$ serc Jego wyznawców wątłą jeszcze roślinke wiary. I oto $w$ chwili, gdy był najniegodniejszy, Jezus prześladowany ukazał się mu i pochwycił go (Fil. 3, 12). Miłością swego boskiego Serca kruszy w nim ,bluźnierce, przesladowce $i$ zuchwalca" (1 Tym. 1, 12) i ezyni najwierniejszym sługą i najżarliwszym głosicielem Ewangelii wśród pogan. W jego słabe ręce kładzie dzieło, od którego zależeć będzie przyszłe nawrócenie i zbawienie świata. Wielkie zaufanie Pana i wielka zaiste łaska. Na każde wspomnienie tej słodkiej dobroci Jezusa zbiera w sercu Apostoła uczucie gorącej wdzięczności i głębokiej pokory.

„Mnie najlichszemu ze wszystkich świętych..." Dając chrześcijanom nazwę świętych, ma Apostoł na myśli nie osobistą, podmiotową świętość wiernych, lecz przedmiotowy stan świętości, w którym znajduje się każdy z nich mocą swego powołania do wiary. Wybrani przez Boga i odłączeni od świata, chrześcijanie weszli w szczególny stosunek do Boga i Jego świętości. Oddani czci i służbie Bożej w duchu i w prawdzie ( $\mathrm{J} 4,24)$, stali się ,rodem wybranym, królewskim kapłaństwem, narodem świętym" (1 P 2,9). W chrzcie św. chrześcijanin otrzymał również świętość wewnętrzną duszy, przynajmniej w zarodku. Otóż świętość stanu obowiązuje go do świętości życia i do ciągłej pracy nad rozwojem i wzrostem świętości wewnętrznej.

Najlichszy ze świętych ma ,gtosić poganom niezgłebione bogactwo Chrystusa". Stanowia je przede wszystkim nadprzyrodzone skarby prawdy i laski, zawarte w umyśle i sercu Zbawiciela. Jezus Chrystus, jednorodzony Syn Boży, przyniósł je z nieba (J 1, 14). Bóg znikomą tylko ezasstkę Swej nieskończonej prawdy wypisał na świecie widzialnym. Człowiek szuka jej poprzez wieki i cieszy się każdym jej promykiem, skoro go odkryje. Nierównie donioślejsze i wspanialsze prawdy o Sobie, o człowieku, jego wartości i przeznaczeniu przekazał Bóg ludzkości w objawieniu. Mówił do niej ongiś przez proroków, a na koniec przemówił przez własnego Swego Syna, którego posłał na świat (do Żyd 1, 2). Jezus posiada pełnię prawdy Bożej, albowiem, ,u nim sq uszystkie skarby madrości i wiedzy" (Kol. 2, 3).

Atoli sama prawda człowiekowi nie wystarczy, ani go nie uszczęśliwi. Potrzeba mu jeszcze łaski i dobra. I te otrzymał Jezus w całej pełni od Ojca i przyniósł na ziemię. Tak więc bogactwo Chrystusa stanowi Jego własne wewnętrzne życie, świat Jego myśli i uczuć; stanowi 
je ubóstwo i wyniszczenie, które on przy jął na Sieble, by'nas ubogacié i wywyższyć (2 Kor 8, 9; Fil 2,6-8); stanowi bosko-leidzka jego miłość tak niepojẹcie ofiarna, cierpliwa i miłosiema; stanowi przebaczenie win, które Jezus nam wyjednał, i życie Boże, które nam wysłużył; stanowią łaski, pomoce i sposoby, które służą do rozwoju życia Bożego w nas: na pierwszym miejscu Sakramenty św. i ofiara Mszy świętej; stanowią je również nadprzyrodzone siły, którymi Jezus umacnia Swych wyznawców i mẹczenników, którymi tak potężnie wspientał swego Apostoła w jego trudach, cierpieniach i walkach. Z bogactwa Chrystusa pochodzą dary mistyczne i pociechy, które odrywają duszę od ziemi i rzeczy doczesnych, by ją podnieść i zjednoczyé z Bogiem.

Bogactwa Chrystusa sa ,niezgtẹbione". Zadnym wysitkiem. rozumu ludzkiego, ani żadną zasługą ludzką nie można ich zdobyć .Nieskończone $\mathrm{w}$ 'swej wartości w oczach Bożych, niewyczerpane są w użyteczności dla ludzi. A właściwością ich jest to, że ubogacają tych, którzy z nich czerpią, nie tylko dla nich samych, lecz i dla drugich. Gdy dobra ziemskie zasklepiają i zacieśniają serca ludzkie, bogactwa Chrystusa dają życie, rozszerzają serce, czynią je źródłem ubogacającym innych. Doznał tego na sobie Apostoł, doznają święci.

Posłannictwo Apostoła nie ogranicza sie do samych pogan .Jest to posłannictwo światła, które zwraca się do wszystkich, żydów i pogan, chętnych i niechętnych, i niby słońce obejmuje ich swymi jasnymi promieniami. Paweł ma, ,oświecać wszystkich, czym jest porzadek tajemnicy, zakrytej od wieków $w$ Bogu, Stwórcy wszystkiego" Tajemnicę tę nazywa Apostoł ,tajemnica Chrystusa" (w. 3), gdyz Chrystus jest jej ośrodkiem. Przez Chrystusa bowiem i w Chrystusie ma być zbawiona cała ludzkość. I to była odwieczna myśl Boża. Jednakże przez wieki Bóg nikomu jej nie ujawnił. Przeczuwali z niej coś nie coś patriarchowie i prorocy Starego Przymierza, lecz był to tylko przedświt. Sam Chrystus Pan, gdy staną na ziemi, odrzucił narodowościowe roszczenia Swych współziomków, Boga głosił Ojcem wszystkich ludzi, dobrych i złych, i wszystkich, nie tylko Żydów, objął pojęciem bliźniego. Dał wyraźnie do poznania, że królestwo, które On zaklada, nie jest z tego świata i nie zacieśni się do jednego narodu. Jednakowoż całej myśli Bożej względem ludzkości Jezus nie wyjawił za Swego życia doczesnego nawet Swym uozniom, a i osobistą Swą działalność ograniczył niemal wyłącznie do tych, co 'z urodzenia byli dziećmi królestwa (Mt 8, 12). 
Dopiero po zmartwychwstaniu, gdy odkupienie ludzkości zostało dokonane, Jezus poucza dokładniej Apostołów o Swym zbawczym dziele i o zadaniu, jakie im pozostaje do spełnienia. Posyła ich na cały świat i każe im pozyskiwać w s z y t k i e n a r o d y na Jego uczniów (Mt 28, 18-20 i równob; Dz. 1, 4-8). Lecz i tych słów Zbawiciela Apostołowie nie zrozumieli (Dz. 1, 6). Na to potrzeba było szczególnego, wyraźnego objawienia. Otrzymał je Piotr w związku z nawróceniem i chrztem Korneliusza $(\mathrm{Dz} 10,9-48)$, a przez Piotra otrzymali i inni apostołowie i wierni $(\mathrm{Dz} 11,5-17)$. Paweł otrzymał je pod Damaszkiem. Już wówczas zrozumiał, że poganie są razem i na równi $z$ żydami ,wspótdziedzicami, wspótczłonkami i wspótuczestnikami obietnicy $w$ Chrystusie Jezusie przez Ewangelie" (Ef 3, 6). Byli oni nie mniej niż Żydzi przedmiotem odwiecznej myśli i nieskończonej miłości Bożego Serca, a teraz w Chrystusie otrzymali z laski i miłosierdzia Bożego te same dobra mesjańskie, które na podstawie obietnicy ofiarowane zostały Żydom (zob. Rz 15, 8-9). Oto treść tajemnicy Chrystusa. A urzeczywistnienie w czasie odwiecznych zamiarów Bożych względem pogan, to „porzadek tajemnicy“, zakrytej od wieków w Bogu. Taka myśl powziąć i tak ją przeprowadzić mógł tylko ten, który jest wszechmocny, "Stwórca wszechrzeczy".

Po odejściu Chrystusa Pana $z$ tej ziemi dzieło zbawienia świata prowadzi Kościół. Jest on czymś więcej, niż społecznością wiernych. Kościół to mistyczny Chrystus, którego wierni są członkami. Wyposażony w bogactwa Chrystusa, Kościół zespala w sobie wszystkie narody, tak różne pochodzeniem, językiem, obyozajami. Różne są jego urządzenia, rozległa działalność misyjna, samarytańska, uświęcająca. Jak Chrystus szedł przez Palestynę, tak Kościól idzie przez świat nauczając i dobrze czyniąc $(\mathrm{Dz} 1,1)$. Otóż i samóżycie i ta różnorodna zbaweza działalność Kościoła jest przedmiotem zatapiania się i zachwytu dla samych umysłów anielskich. „Przez Kościót bowiem ma siẹ okazać zwierzchnościom i władzom na niebiosach wieloraka madrość Boża“. Aniołowie pośredniczyli często między Bogiem a ludźmi, nie mieli jednak jasnego wglądu w rządy Opatrzności. Nie wiedzieli, dokąd prowadzą drogi, którymi kroczyła ludzkość. Patrzyli na życie Jezusa, ma Jego poniżenie i chwałę, lecz i wtedy jeszeze mogli byli pytać: jaka ostatecznie tkwi w tym myśl Boża? do czego to wszystko zmierza?... W Kościele rozpoznają aniołowie zbawezą działalność Chrystusa, Kościól jest dla nich ostatecznym wyjaśnieniem wszechmądrych zamiarów Bożych względem świata. 
To wszystko dzieje się, ,zgodnie z odwiecznym postanowieniem, które Bóg powziąt w Chrystusie Jezusie, Panu naszym". Chrystus zjawił się przy końcu wieków, lecz był pierwszy w myśli Bożej. W nim powziął Bóg Swe odwieczne postanowienie co do zbawienia ludzkości, w nim spełnił je w czasie i spełniać będzie przez Kościół ustawicznie aż do skończenia świata. Chrystus jest Panem naszym. Pan to Jego imię, które jest ponad wszelkie imię (Fil 2, 9). Jemu bowiem Ojciec niebieski oddał wszelką władze na niebie i na ziemi (Mt 28, 18) i wszelki sąd nad światem (J 5, 22, 27).

„W nim tè̇, przez wiare w niego, mamy ufność i śmiały przystẹp do Boga". Jest coś czarującego w tych słowach Apostoła. Wypowiada je do wiernych, którzy niedawno jeszcze, oddani bałwochwalstwu, czuli się osamotnieni na świecie i byli smutni. Posiadali wprawdzie wiele bogów, lecz nie mieli Boga, nawet drogi nie znali do Niego. Teraz, gdy uwierzyli w Jezusa Chrystusa i przez chrzest zostali wszczepieni w Jego mistyczne Ciało, wraz z wiarą spłynẹła do ich serc jakaś radosna pewność. Duch Św. wniósł do ich dusz nowe życie, a w sercach rozlał miłość Bożą. Dotąd ,obcy i przybysze“ poczuli się teraz „wspótobyuatelami świẹtych i domovnikami“, co wiẹcej dziémi Bożymi (Ef 2, 19). Przez wiarę w Syna mają otwarty dostẹp do Ojca. Mogą zbliżać się do Boga tak jak dziecko zbliza sie do swego kochającego je ojca, by odpocząc na jego kochającym je sercu.

Chrześcijanin, który odezuwa prawdę i siłę tych słów Apostoła, wie dlaczego i po co żyje. Świadomość zjednoczenia z Bogiem napełnia jego serce słodką radością i męstwem, opromienia jego codzienne troski i kłopoty... ,Przystapmy wiẹc z radościa $i$ ufnościa do tront laski“ (Zyd 4, 16).

Posłowanie Apostoła do pogan, głoszenie im bogactw Chrystusowych nie było rzeczą łatwą. Wymagało ogromnego wysiłku i całkowitego zaparcia samego siebie. Pokonywać musiał największe trudności i znosić cierpienia, które spotykały go ze strony jego współrodaków. Znienawidzony i ścigany przez nich musiał ustawicznie zmieniać miejsce pobytu. Od dłuższego zaś czasu skuty jest w łańcuchy i list pisze z więzienia. To też do serca Apostoła wkrada się obawa. Czy dla świeżo nawróconych, nie utwierdzonych jeszcze dostatecznie w wierze, jego cierpienia i prześladowania nie staną siẹ powodem do zniechẹcenia. Czy ten lub ów nie odwróci się od Chrystusa i nie cofnie $z$ obranej drogi. Gdy im wiẹc przedstawił swe wzniosłe posłannictwo, na konicu dodaje prośbe. „Dlatego proszę, nie upadajcie na duchu, z powodu 
ucisków mych za was". Wraśnie za nich, za ich równouprawnienie jest prześladowany. Cierpienie nie tylko nie przynosi mu ujmy, lecz zaszczytem jest dla niego. Nie mniej zaszczytem jest dla wienych, takiego mieć Apostoła. Jego bowiem cierpienie potwierdza prawdę o apostolstwie do pogan. W cierpieniu przejawia się ta sama moc Chrystusowa, która towarzyszyła mu w podróżach i trudach apostolskiej pracy. Cierpienie sprowadza również błogosławieństwo Boże nie tylko na osobẹ Apostoła, lecz i na wiernych, za których cierpi. A więc w górę serca...

Po tym krótkim zatrzymaniu się nad swym posłannictwem powraca św. Paweł do rozpoczętej poprzednio myśli i snuje ją w postaci modlitwy. Niezrównana jest godność i wielkie przywileje. które wierni od Boga otrzymali. Wielkich również potrzeba im łask, by mogli sprostać swemu wzniosłemu powołaniu. O te raski Apostoł modli się dla nich. Przede wszystkim o wewnętrzną moc Ducha Św. i o głẹboką wiarę, o utwierdzenie ich w miłości, by mogli pojąć niezmierzoną tajemnicę Bożą i poznać miłość Chrystusa, o napełnienie ich wszystkimi dobrami Bożymi.

„Dla tej przyczyny zginam kolana przed Ojcem". ... ic nie wyraża piękniej prawdziwego usposobienia duszy względem Boga, jak postawa ciała"1). Zydzi modlili się zazwyczaj stojąc, lecz i postawa klęcząca nie była im obca. Tak na kolanach modlił się Salomon przed ołtarzem całopalenia w dzień poświẹcenia świątyni (2 Par 6, 13). Chrześcijanie za przykładem Jezusa (Łk 22, 41) modlili się najozéściej w postawie klęczącej ( $\mathrm{Dz} 7,60 ; 9,40 ; 20,36 ; 21,5)$. Modlitwa Pawła jest wyrazem jego kornej czci dla Majestatu Bożego i przejawem żaru apostolskiego serca. A towarzyszy jej niezachwiana ufność. Apostoł modli się bowiem do „Ojca, od którego bierze swe imię wszystko, co nazywa się ojcostwem un niebie i na ziemi" (w. 15). ,Kazdy datek dobry i kazdy dar doskonały pochodzi z góry od Oj̣ca światłości" (Jak 1. 17). B6g' jest źródłem wszystkich dóbr i wszelkiego życia przyrodzonego i nadprzyrodzonego. Od Niego pochodzi wszelkie ojcostwo, czyli wszelka społeczność zarówno w niebie, jak na ziemi.

Bóg jest wspaniałomyślny. Apostoł doznał na sobie jego nieskończonej hojności i wie, że Ojeiec nie mierzy swych darów naszym ubóstwem ani naszą modlitwą, lecz swą dobrcią i chwałą. Dlatego prosi, aby Ojciec niebieski użyczył wiernym swych dóbr ,według bo-

1) W. H. Griffith Thomas, The Prayers of St. Paul, 1927, str. 113. 
guctwa swej chwaly". Easki, o które tak pokornie, a zarazem tak ufniei gorąco siẹ modli, są cząstką naszego ubłogosławienia w Chrystusie. Sa one nieodzowne do pełnego rozkwitu i wykończenia naszego życia nadprzyrodzonego.

Rozrost życia Bożego w nas wymaga na pierwszym miejscu umorzenia starego człowieka $z$ jego namiętnościami i samolubstwem. Na jego gruzach zapanować ma w nas nowy człowiek, chrześcijanin, ma zapanować Chrystus. Jemu powinny byé poddane nasze władze duchowe; w naszym wewnętrznym życiu powinien zapanować ład zamiast rozterki. Otóż o własnych siłach ozłowiek, náwet chrześcijanin. nie jest zdolny to przeprowadzić. Potrzeba mu wyższych, nadprzyrodzonych sił, a te pochodzą wyłąoznie od Ducha Św., który jest Duchem mocy. Dlatego pierwsze, o co Apostol prosi: „zeby za sprawa Ducha Swiẹtego" wiemi ,uzmocnili się potęznie w wewnẹtrznego czlowieka". Może zewnẹtrzne życie ciała być słabe, byle duch był silny. Duch Św. wzmocni nasze życie wewnętrzne, oświeci nasz umysł, spotęguje wolę, w sercu rozleje miłość Bożą, a sumienie uczyni wrażliwym i podatnym. na wszystko, co dobre. Chrześcijanin tak umocniony przez Ducha Świętego staje się, ,człowiekiem duchowym“, który postẹpuje w życiu nie za pociągiem swych niższych skłonności, lecz za natchnieniami Ducha. A gdzie jest Duch Pański, tam jest wolność (2 Kor. 3, 17).

Chrześcijanin, umocniony przez Ducha Świętego staje się równiė zdolny do coraz ściślejszego zjednoczenia z Jezusem. I oto modli się żeby „Chrystus zamieszkat przez wiare w sercach waszych“. Przez. wiare przychodzi ten boski Gość do du'szy i według tego, jak pogłẹbia się i działa wiara, daje duszy odczuć swą słodką obecność. „Gdy Bóg chee zawładnąc całkowicie jakąś duszą, zaczyna od pozyskania jej umysłu, udzielając mu wzniosłej wiary", mówi Ojeiec Lallemant ${ }^{2}$ ). Atoli wiara, przez którą Chrystus mieszka w sercu chrześcijanina, to nie sucha wiara samego rozumu; musi ona obejmować także serce. Bo tylko przez serce dusza może wejść w ścisłą łączność z sercem i duszą Pana, może zrozumieć jego nauke i jego miłość. Dopiero taka dusza może się stać owym stałym mieszkaniem, którego szukał Bóg-Człowiek, gdy chodził po ziemi i którego dziś szuka po pustynnym bezdrożach dusz ludzkich ${ }^{3}$ ). Taka dusza napawa się duchem Zbawiciela, przyswaja

2) Al. Pottier S. J., La Vie et la Doctrine Spirituelle du P. Louis Lallemant, 1924, str. 76 .

3) Zob. Bp Ottokar Prohaska: U źródła żywych wód. Rozmyślania o Najśw. Sercu Jezusa, 1947, str. 19 n. 
sobie jego zapatrywania i jego uczucia; staje się coraz bardziej przystępna dla wielkich myśli Bożych i wżywa się w nie. Jej umysł obejmuje w jasnym świetle tajemmice i prawdy wiary, pojmuje coraz lepiej ideał chrześcijańskiej doskonałości i rozumie wzór życia, zostawiony nam przez Pana. Chrystus mieszka stale w takiej duszy, kieruje nią i działa w niej. Wiara to odpowiedź duszy na pukanie Zbawiciela do jej drzwi.

Chrześcijanin zjednoczony z Chrystusem i ży jący mocą Ducha jest niby drzewo potężne, zapuszczające coraz głębiej swe korzenie w glebę, na której rośnie; to dom wspaniały; utwierdzony na skale. na której stoi. Tą glebą i skałą chrześcijanina jest miłość. Apostoł modli się, żeby wierni byli ,wkorzenieni i utwierdzeni w miłości“. Nie określa bliżej, jaką miłość ma na myśli. Chodzi bezwątpienia o miłość Bożą, której Apostoł doznał przy pierwszym zetkniẹciu się z Jezusem pod Damaszkiem. Napełniła ona wówczas jego serce, zniszczyła w nim dumnego faryzeusza, zapatrzonego w Prawo, a zrodziła najwierniejszego ucznia i najżarliwszego Apostoła. Wiara zachowuje zawsze swe podstawowe znaczenie, lecz pierwiastikiem czynnym w życiu chrześcijańskim jest miłość ( $\mathrm{Rz} 8,31$-39). Miłość to najezystsza i najsłodsza atmosfera, w której chrześcijanin ma swe bytowanie, porusza się i żyje.

Utwierdzenie w miłości czyni chrześcijanina zdolnym do zrozumienia rzeczy wielkich i wzniosłych. Apostoł prosi, żeby wierni tak rzygotowani ,mogli uraz ze wszystkimi świętymi pojać, juka jest rozległość i dalekość, wzniostość i głębia" odwiecznej a teraz urzeczywistniającej się w nich tajemnicy. Wielka jest ta tajemnica, tak wielka, jak miłość Boża, z której odwiecznie się poczęła. Wzniosła i czysta, jak miłość, ma za przedmiot przebóstwienie czlowieka przez zespolenie go z Chrystusem. Głęboka jest, jak miłość, która zstępuje aż na dno duszy ludzkiej, by ją podnieść i uszlachetnić. Rozległa jest jak miłośé, gdy rozciąga się i obejmuje wszystkich ludzi, zarówno pogan, jak Zydów, i każdemu towarzyszy przez jego życie. Jest również daleka jak miłość; poczęła się w wieczności, ciagnie się poprzez wieki i trwac będzie wiecźnie. Modlitwa ta Apostola jest ekstatyczna. W objawieniu otrzymał on zrozumienie tajemnicy Bożej i doznał na sobie nieskończonej Miłości. Jednakowoż tego, co zrozumiał i czego doznał, w żaden sposób wypowiedzieć nie może. Są tu rzeczy nadprzyrodzone i tajemnicze, żaden język ludzki nie ma wyrazów na ich wysłowienie. Mówiąc o ich wymiarach, chce raczej powiedzieć, że są one niezmierzone i niewysłowione. 
„Kto mnie widzi, powiedział Jezus, ten widzi i Ojca“ (J 14,9). Odwieczna i nieskończona miłość Boża ucieleśniła się w osabie Chrystusa, w którym cała pełnia bóstwa mieszka (Kol. 2, 9). Apostoł życzy więc wiennym i prosi o to dla nich, ,żeby poznali miłość Chrystusa“". Poniekąd łatwiej ją poznać, gdyż promienieje nie tylko z postaci Zibawiciela i z Jego Najsł. Serca. Miłość Chrystusowa promienieje takíze z Jego żłóbka w Betlejem i z Jego warsztatu ciesielskiego w Nazarecie; promienieje $\mathrm{z}$ kropel wody rozlanej przy umywaniu nóg uczniom w Wieczerniku i z kropel krwi Zbawiciela, wylanej na drodze krzyżowej i na Kalwarii. Miłość Chrystusowa ku nam promienieje z Jego krzyża i promienieje $\mathrm{z}$ Eucharystii, którą nam pozostawił na dowód umiłowania nas aż do końca. Jednakowoż Apostoł przestrzega wiernych, że i miłość Chrystusowa ,przewyżza wszelkie poznanie“. I ona gorętsza jest, niz ogień, mocniejsza niż śmierć, głębsza niż morze, wyższa niż niebo ${ }^{4}$ ). Nawet błogosławieni i aniołowie nie obejmuja jej nigdy, będą zawsze zdumieni jej nowością i bezmiarem. Bóg jeden obejmuje ją całkowicie.

Miłości Chrystusa żaden umysł stworzony nie obejmie i nie pozna. Można jej doświadczyć, można jej doznać, jak doznał Apostoł, dorznali inni. „Umitowat mnie i wydał się dla mnie", powtarzać będzie Paweł, jakby w zachwycie (Gal 2, 20). A miłość Chrystusa doznana rozpala w sercu, które jej doznało, wzajemną miłośé. Kto w ten sposób poznlał miłość Chrystusa, dla tego żadna rzecz doozesna nie ma wartości. Ten bez zastrzeżeń oddaje się Chrystusowi i Jego sprawie na prace, cierpienia i trudy. Dla imienia Pana Jezusa gotów jest, podobnie jak Apostoł, nie tylko więzienie cierpieć, lecz i śmierć ponieść (Dz. 21, 13). „Któz nas odlaczy od miłości Chrystusa?... Bo jestem pewny, że ani śmierć ani ̇ycie, ani aniotowie, ani władze, ani teraźniejszość, ani przyszłość, ani potẹga, ani wysokość, ani glębokość, ani żadne inne stworzenie, nie zdoła nas odłaczyć od miłości Bożej, która jest w Chrystusie Jezusie, Panu naszym" (Rz 8, 35, 38-39). Miłość Boża jest najcenniejszą i najpiẹkniejszą treścią duszy - największym czynem, jaki człowiek wylkonać może.

Ostateczne atoli pragnienie Apostoła dla wiernych jest jeszcze wyzsze. Chce i modli się, ,żeby zostali napelnieni wszystka pełnościa Bożą". Owa pełność Bюża, to pełność doskonałości, której Bóg jest źródłem; to nieprzebrane skarby nadprzyrodzonych łask, cnót, darów i pociech, których bez miary udziela Bỏg świętym. Pelność Boża, to najwyższy

4) J. Huby S. J., Saint Paul, Les Épitres de la Captivité. 1935, str. 189. 
ideał i cel życia chrześcijańskiego na ziemi. Gdy ona zostanie osiąnięta. wówezas ciało mistyczne, Kościół, dojdzie do pełnego rozwoju i tajemnica Chrystusa zostanie w całości urzeczywistniona.

Widok wspaniałych zamiarów Bỏ̇ych względem wybranych wprawia Apostoła w zachwyt. Jego modlitwa przemienia się we wzniosly hymn uwielbienia Boga, Jego niewshowionej dobroci i nieskończonej wezechmocy (3, 20-21). „Temu zaś, który przez dziatajaca ul nas moc swoja moźe uczynic nierównie wiecej, niz to uszystko, o co prosimy, lub co pomyślé zdolamy: Jemu niech bẹdzie chwata un Kościele, (tym najeudowniejszym przejawie Bożej mądrości) i w Chrystusie Jezusie, (który sam jeden może Majestalowi Bożemu oddać godną chwałę; Jemu niech bedzie chwala) po uszystek czas i przez unecznośc cala. Amen".

Es. Walenty Prokulski T. I.

\section{ŚWIATOPOGLA D \\ STAROWSCHODNI A BIBLIJNY}

II.

We wspomnianym już poprzednio (w numerze I ,Ruchu“, $21 \mathrm{nn}$ ), eposie babilońskim ,enuma alisz" czytamy, jałk Tiamat zawiesiła na piersi Kingu, swego kochanka, ,tablice przeznaczenia“ (tup szimati). Po zwyciestwie odniesicnym nad Kingu i Tiamat przywłaszczył sobie bóg Marduk owe tablice jako znak najwyższej wła$\mathrm{d} z y^{1}$ ). Według innych babilońskich mitów i tekstów astrologicznych wszystko ma swoje przeznaczenie już od dawien dawna, od wieków "). Jeżeli Marduk zawiesza sibie tablice przeznaczenia, odebrawszy je poprzednio swemu przeciwnikowi, wynika z tego, jakie znaczenie przypisywali tablicom tym sami bogowie; i oni podlegaja przeznaczeniu.

Także w legendzie o Zu, ptaku burzy, jest mowa o tych tablicach przeznaczenia, których porbawil $\mathrm{Zu}$ boga Ellil. Bóg Anu wzywa różnych bogów, żeby zmusili Zu do wydania tablic. Wszyscy sie wa-

1) H. Winkier. Keilinschrftiches Texthuch 19093, str. 98. 111.

2) B. Meissner, Babylonien u. Assyrien II 125. 